\title{
Openness and Urban Governance: How Transparency Erodes Local Government
}

\author{
Frans Jorna \\ Saxion University of Applied Sciences, The Netherlands \\ f.b.a.jorna@saxion.nl
}

\section{ABSTRACT}

Local government political leaders have a hard job these days. More and more they are confronted by citizens demanding transparency and a say in the production of social goods. Challenging the hegemony of local government, they connect their resources to come up with grass roots solutions. Fear of litigation claims and an increase in the complexity of policymaking and administration and fiscal scarcity render local administrations risk averse.

How to effectively structure the frontline between local government and local communities? Open and collaborative governance approaches hold the promise of developing to mediate these tensions, but what are the implications for the way local democracy, local government and local administration work? This article looks at the ugly face of trust in collaborative and open governance on the basis of a comparative casestudy from Apeldoorn (The Netherlands). The article identifies and analyses patterns of (a lack of) open governance and offers alternative models to the organization of the frontline between local government and society.

Keywords: urban governance, open government, political-administrative relations, civic participation

JEL:D73

\section{Urban Governance and Transparency}

Concepts like "transparency" and "openness" loom large in local governance these days. As the traditional approach to local government has given way to local governance as a heterogeneous approach which focuses on publicprivate-social partnership in affecting and governing the local community's life instead of the execution of local government tasks, it is no longer clear where local governance starts and ends. The same could be said for defining concepts like "mandate" and "authority". As ever fewer people turn up at local elections and local councillors have to govern a myriad of private-public ventures that are only partially under their control, transparency withers. Government. International Public Administration Review, 13(3-4), 161-183. 
Local governments across Europe experiment with ways to increase transparency, accountability and responsiveness. There are indications, however, that these efforts to enhance the "openness of government" confuse and obstruct traditional mechanisms of democratic control (Meijer \& Bolivar, 2015). This article examines the impact of open government by means of increased transparency on traditional local democratic practices in the Dutch city of Apeldoorn, known as a frontrunner in engaging citizens in the governance of their city. More precisely, it maps the effects of efforts to increase transparency through new engagement oriented modes of urban governance on traditional democratic practices.

The question addressed in this article is:

How do changes promoting open and collaborative governance in state-society and public-private interactions affect formal local decisionmaking?

The interface between local government and urban society is often messy. From a formal representative democratic point of view, citizen engagement not only holds promises, but also contains threats to local democracy such as co-optation of local government but (a cooperative of) private interests; contestation in the form of increased negative social action against collective decisions on the basis of not-in-my-back-yard motives; skewing the representation of interests, favouring the politically and bureaucratic competent citizens over citizens that do not have a clue of how government works or do not have the resources to try and influence; or the dominance of here-and-now concerns and interests over longer term "weaker" interest and social goals.

In paragraph 2 the literature on urban governance and openness is reviewed. This review culminates in the formulation of four hypotheses in paragraph 3. Paragraph 4 describes the research methodology applied to track and trace the (unintended) impact of increased transparency on local government. Paragraph 5 provides an overview of the way the city of Apeldoorn has sought to structure its boundary with society so as to increase the openness of local government to its citizens. Paragraph 6 introduces the three cases that were selected in terms of context, content, time, domain and players, as briefly as possible ${ }^{1}$. In paragraph 7 , we analyse the mechanisms that operated in these cases and the ways in open government can lead to unintended consequences, the factors at play, the strategies that local governors apply to prevent and combat negative or unintended consequences. Paragraph 8 analyses the mechanisms by means of applying the hypotheses. In paragraph 9, we discuss the findings, provide an answer to the research question and

1 This article is the product of cooperation between the City of Apeldoorn and Chair of Governance of Saxion University that carries a research program into Open Government. In close collaboration, three cases of open government and unintended consequences were selected and analysed. 
discuss the relevance of this article for the field of open urban governance and the concept of transparency.

\section{Openness and Urban Governance: Theoretical Approaches}

Urban governance in this day and age is contested and complex. The sheer number of people dwelling in cities, their mobility, their heterogeneity, the speed of social and technological development and the increased interdependence between the cities and the rest of the world impair their governability (Van Gunsteren, 2006). The "urban citizen" is a powerful, unpredictable (Beck, 1992), well informed effective organizer capable of garnering support for social action without the help of big institutions such as government.

Traditional representative democracy in cities is confronted with a number of challenges. As to representation, it is less and less clear who is being represented and who wishes to be represented in formal assemblies. As the voter turnout decreases, how does democracy ensure the legitimacy of local councils and councillors? The resilience of cities, their capacity to deal with the unknown, is impaired by the growing complexity of urban administration. The number of tasks of local governments, the size of municipal budgets and their importance for citizens as "first governments" has increased strongly, but so has the dependence of local governments on central government, the complexity of programs and the need to rely on concerted action with other local and regional actors, greatly increasing the risks local governments run. As the heterogeneity of urban population increases, the local social contract becomes strained and solidarity wanes. Contestation of political decisions, by social action, political campaigns or legal procedures impair the capability of local governments to affect the status quo while simultaneously increasing the conflicts of interest between its inhabitants. The rift between young and old, rich and poor, newcomers and "aboriginals" grows. The ability of local inhabitants to effectively organize themselves limits the ability of local government to enforce political decision and general rules.

For city councillors, these trends lead to questions about the validity of their work and mandate. The job at hand is more time-consuming than ever, but public opinion is against them. In the past decades, the length of the terms councillors serve has decreased, while the number of councillors leaving midterm elections has increased. The information that they have to their availability to take decisions has multiplied dramatically, as has the impact of municipal decisions on the lives of its inhabitants, but the expertise that councillors can call upon is still organized in the same way it was in the 19th century. Essentially, urban governance is governance by amateurs, in a day and age where knowledge is dispersed and society is much more knowledgeable than it used to be. The number of formal grievances, complaints, law suits etcetera increases, while the readiness and ability of urban citizens 
to participate in formal democracy has dwindled. Efforts at democratic innovation such as plebiscites, referenda, neighbourhood councils and interactive policymaking appear futile, hardly attract interest, and the ones that are interested are the usual suspects that already participate in formal ways.

Apparently, cities can no longer be ruled from above. In an effort to reinforce legitimacy and effectiveness, cities around the globe have added elements of participation to their repertoire by increasing transparency of data (Townsend, 2013). Involving citizens in the maintenance of their neighbourhood, budgeting procedures and public procurement, they seek to engage society in the fabric of governance fabric. This article contends that this shift is more than an addition and elaboration of our existing government paradigms (Goldstein, 2013). It suggests that a true democratic turn is at hand, transforming local governance, partly destroying it as well. Post-bureaucratic government has been replaced by "open government" and "do it yourself democratic" practices built on three approaches to enhance transparency:

- Open data ${ }^{2}$, even in domains hitherto dominated by hybrid contracting and procurement procedures (e.g. public transport; energy, water and sanitation);

- Open procedures and freedom of information, such as open spending, crowd-sourcing policy, participatory evaluation and participatory budgeting;

- Government participation in social self-governance of social services and regulation instead of public engagement in local government providing public goods, in the form of social cooperatives, face-to-face citizen assemblies and other citizen communes.

Citizen engagement is not an either/or issue. Five forms of engagement are distinguished ${ }^{3}$ (Table1).

2 Following the definition in the Open Government Charter (http://www.opengovdata.org/ home/8principles), open data: Data Must Be Complete. All public data are made available. Data are electronically stored information or recordings, including but not limited to documents, databases, transcripts, and audio/visual recordings. Public data are data that are not subject to valid privacy, security or privilege limitations, as governed by other statutes. Data Must Be Primary. Data are published as collected at the source, with the finest possible level of granularity, not in aggregate or modified forms. Data Must Be Timely. Data are made available as quickly as necessary to preserve the value of the data. Data Must Be Accessible. Data are available to the widest range of users for the widest range of purposes. Data Must Be Machine processable. Data are reasonably structured to allow automated processing of it. Access Must Be Non-Discriminatory. Data are available to anyone, with no requirement of registration. Data Formats Must Be Non-Proprietary. Data are available in a format over which no entity has exclusive control. Data Must Be License-free. Data are not subject to any copyright, patent, trademark or trade secret regulation. Reasonable privacy, security and privilege restrictions may be allowed as governed by other statutes. Finally, compliance must be reviewable. A contact person must be designated to respond to people trying to use the data. A contact person must be designated to respond to complaints about violations of the principles. An administrative or judicial court must have the jurisdiction to review whether the agency has applied these principles appropriately.

3 Retrieved from http://c.ymcdn.com/sites/www.iap2.org/resource/resmgr/imported/ IAP2\%20Spectrum_vertical.pdf 
Table 1: Five forms of citizens engagement

\begin{tabular}{|c|c|c|c|c|}
\hline Inform & Consult & Involve & Collaborate & Empower \\
\hline $\begin{array}{l}\text { To provide } \\
\text { the public } \\
\text { with objective } \\
\text { and balanced } \\
\text { information to } \\
\text { assist them in } \\
\text { understanding, } \\
\text { the problem, } \\
\text { alternatives, } \\
\text { opportunities } \\
\text { and/or solutions. }\end{array}$ & $\begin{array}{l}\text { To obtain } \\
\text { public feedback } \\
\text { on analysis, } \\
\text { alternatives and/or } \\
\text { decisions. }\end{array}$ & $\begin{array}{l}\text { To work directly } \\
\text { with the public } \\
\text { throughout } \\
\text { the process } \\
\text { to ensure that } \\
\text { public concerns } \\
\text { and aspirations } \\
\text { are consistently } \\
\text { understood and } \\
\text { considered. }\end{array}$ & $\begin{array}{l}\text { To partner with } \\
\text { the public in each } \\
\text { aspect of the } \\
\text { decision including } \\
\text { the development } \\
\text { of alternatives and } \\
\text { the identification } \\
\text { of the preferred } \\
\text { solution. }\end{array}$ & $\begin{array}{l}\text { To place final } \\
\text { decision making in } \\
\text { the hands of the } \\
\text { public. }\end{array}$ \\
\hline
\end{tabular}

Source: http://c.ymcdn.com/sites/www.iap2.org/resource/resmgr/imported/ IAP2\%20Spectrum_vertical.pdf

The literature on public participation offers us one more conceptual tool in analyzing participation strategies. There are two different ways in which local governments organize transparency (Newman, Barnes, Sullivan, \& Knops, 2004): "targeted transparency" and "embedded transparency". Targeted transparency represents a distinctive category of public policies that, at their most basic level, mandate disclosure by corporations or other actors of standardized, comparable, and disaggregated information regarding specific products or practices to a broad audience in order to achieve a specific public policy purpose. Thus, targeted transparency does not require specific technologies, performance targets, or taxes. Instead, it relies on thousands of individual choices by information disclosers and users who interact to establish acceptable risk levels or improve organizational performance. Embedded transparency, in contrast, builds on already existing processes; does not create new institutions, but builds on existing ones; and builds on the engagement of existing stakeholders.

\section{Hypotheses}

This article looks at what happens on the boundary between local government (city) and society (citizens). This boundary has been constitutive of public administration. It is designated with two distinctions: state-society and publicprivate.

The state-society distinction is the core nucleus of modern Western thinking about government. Max Weber (2014) wrote much of his work on the interrelation between the two, and even nowadays the distinction still prevails in most discussions of public administration. The state - read local government - functions as a social contract between free citizens, giving up their full autonomy, receiving equality before the law, due process, habeas corpus and other safeguards in return. Society provides crucial elements of support for a state to be effective, and the state is critical to collective action in society (Sellers, 2010).

There is one other crucial distinction to be discussed: the public-private distinction. This is one is less clear than the state-society distinction 
and covers at least two different conceptualisations: 1) political vs. social (read: the absence of the state, representation, generalisation; instead, direct interaction between private interests); and 2) social versus personal, read: collectivist versus individualist approaches. In terms of governance, the confusion is much less troubling: we have private law versus administrative law etcetera (Weintraub \& Kumar, 1997).

The frontline between ordinary citizens and their government, and the whole process of giving/receiving mandates and organizing accountability, can thus be conceptualized in four ways (Figure 1).

Figure 1: The public-social frontline

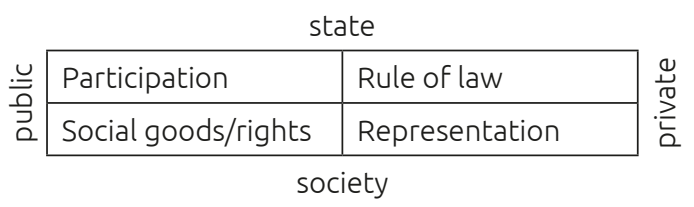

Both distinctions are about balancing interests: the individual versus the collective; the individual versus the state; inhabitants versus citizens; and elected versus non-elected. Basically, democracy functions as a control mechanism: it is to ensure the balance of powers and safeguard our "own interest" (in whichever way conceptualized), lest things might run out of hand.

Based on this framework, we test four hypotheses:

- Participation: Organized representation is essentially elitist. It favours bureaucratic competence.

- Rule of law: Including current stakeholders rigs fair and impartial political procedure.

- Social goods and social rights: Tough political decisions that require objectivity and yes-in-my-back yard are overly simplified to cater for populism.

- Representation: By including private stakeholders focused on their short term interest, long term horizons, weaker interest and long term social contracts on solidarity between generations and haves/havenots are excluded, burdening future developments with todays trade-offs.

Let us briefly describe the pedigree of each hypothesis. The elitist argument is rooted in the political science literature on pluralism. Lobbying essentially puts a bonus on the ability of highly educated well-off elites to influence decision making (Lindblom, 1993). Although Stoker (2010) contends that in modern day politics political elites seek a direct power base among the electorate because elites are no longer able to control "their" clientele and media power has admittedly changed the electoral landscape, political elites are still essentially oriented on maintaining the status quo, read: the stakes of current elites (Farrell \& Drezner, 2008). Representative politics is still 
structured unequally despite the growing influence of the media and other trends (Marsh, Richards, \& Smith, 2003).

The hypothesis on fairness of procedure takes the impossibility of state objectiveness as point of departure. The state (read: local governments) favours and defends the status quo and the interests associated with them. It has a vested interest in (for instance) the land acquired for urban development; the expertise acquired in civil society organisations that have been implementing and administering urban programs in the social domain for decades; the use of new infrastructure developed with large sums of money. Local governments are therefore prone to rig objective and transparent procedure for interest and information that reinforce their past positions and decisions.

The hypothesis on over-simplification and lack of objectivity is related to this partiality. Local government cannot be objective, and more so in this day and age, where political questions are so complex and positions and information on them abounds. Any point of view can be backed by figures and argumentations, and the clearer these can get communicated in sound bites, the better. Then and therefore, Ockham's razor in the political domain applies: the simpler answers are the better, even if this amounts to oversimplification.

The hypothesis on underrepresentation of future or outside voters is a corollary of those first three hypotheses. If vested interests can be defended much more easily than complex policy options favouring interests not yet powerful enough to be heard, they will quietly be ignored and organized out of the process.

\section{Research Design}

To study the mechanisms on the interface between city government and society, the process of case selection that we conducted with representatives of the city of Apeldoorn was focused on "worst cases": incidences of citycitizens interaction where reportedly all actors involved reported imbalances and imperfections in the way in which the two systems related. To allow for a comparative analysis, only cases from the last council period (2010-2014) were selected. One second criterion was the publication of the Councils Report on its own functioning leading up to the political crisis on urban development land acquisition. Furthermore, we looked for a spread over the different domains of urban policy ${ }^{4}$ to ensure representativeness. One final criterion was the "freshness" of the cases: to allow for a reliable reconstruction, no evaluation involving the main actors had yet been carried out.

The selection process was conducted by representatives of the city management team and the secretariat of the council. It resulted in the identification of three cases: the establishment of an emergency winter

4 Social policy, urban development, infrastructural planning 
shelter in the 'De Maten' neighbourhood in 2011; an urban development project in the village 'Loenen'; and the development of a new infrastructural grid for the future 'Zuidbroek' neighbourhood.

For each of these three cases, an appreciative inquiry group interview was organized with representatives of all participants around the table: councillors, executive council members, civil servants of diverse categories, representatives from neighbourhood or village councils, representatives of non-governmental organizations involved and private citizens/entrepreneurs. The secretariat of the council in cooperation with city councillors were asked to provide an actor analysis and identify the people involved. These were then invited by the city of Apeldoorn to participate. Only two actors refused to take part in the group interview, instead requesting an individual interview, which was granted.

In each of the appreciative inquiry interviews, the participants were asked to provide a chronological account of the way grass-roots initiatives had originated, the way these initiatives had been developed in cooperation with city hall, the rounds of administrative (civil servant) advice, decision-making in the executive council, the framing of council proposal and finally decisionmaking in the city council itself. The interviews were based on a desk research set of 1) formal documents describing the decision-making process 2) a media analysis. The interview reports were focused on the mechanisms, not on acts of individual actors. As to these mechanisms, in each description, we focused on five aspects (Krenjova \& Reinsalu, 2013):

$\begin{array}{ll}\text { Rules of the game: } & \text { Who determines the rules of the game? } \\ \text { Participation: } & \text { Which participation mechanisms are used? } \\ \text { Deliberation: } & \text { What is being deliberated? } \\ & \text { How do participants cooperate, communicate } \\ & \text { and make decisions? } \\ \text { Empowerment: } & \text { What role does civil society play? } \\ \text { Control and monitoring: } & \text { Who checks the implementation? }\end{array}$

The mechanisms identified were validated in two sessions with representatives of the urban management team, the secretariat of the council and civil servant involved. The analysis presented in this article was developed on the basis of these sessions. We proceed to describe the state-society frontier in Apeldoorn and then describe the three cases.

\section{City-Citizens Frontier in Apeldoorn (NL)}

The city of Apeldoorn is located in the centre of the Netherlands at some $60 \mathrm{kms}$ east from the Dutch city hub comprising Amsterdam, Rotterdam, The Hague and Utrecht. According to Dutch standards, it is a rather green city that in the boom of 1970s and 1980s as a New Town quickly grew to some 150.000 inhabitants, largely through the concentration of first manufacturing firms 
and then insurance companies and central government public service agencies as part of a Dutch national policy to deconcentrate public services over the country and have all regions profit from public employment ${ }^{5}$. Consequently, in comparative terms, Apeldoorn is relatively homogenous and stable, with a rather big cohort of middle-aged inhabitants. Apeldoorn's population is according to Dutch standards rather well off in terms of household income and living standards. It is one of the larger municipalities of Netherlands in terms of territory. Lying on the frontier of the largest Dutch National Park Hoge Veluwe, it covers an area of $350 \mathrm{~km}^{2}$ and consists of nine villages and ten hamlets.

Because of its size, composition and history of rapid growth as a New Town, Apeldoorn has a political history of hands-on, project-oriented government and direct connections between city hall and the neighbourhoods and hamlets. The ties and links between city hall and the city are traditionally strong and intense, the style of urban governance collaborative. Social partners, companies and entrepreneurs constitute crucial partners in urban development, management and policing. The city government has a long tradition of neighbourhood oriented policymaking: (participative) district budgeting, neighbourhood development plans, neighbourhood based management of the public space ${ }^{6}$.

Owing to this executive style of "getting it done" the ratio of civil servants per 1.000 inhabitants in Apeldoorn is relatively small". Large parts of policy administration and implementation are executed by non-governmental organisations and other related parties, with limited direct political control by the city council. The lack of formal direct political control is compensated through recruitment mechanisms. In line with the New Town history of Apeldoorn, most of the non-governmental organisations are staffed and led by people coming from the same mixed political-cultural elite ${ }^{8}$.

This stability in terms of governance tradition is mirrored in a politically stable council. Apeldoorn has experienced a prolonged period of one ruling coalition dominated by two centre/centre-right parties (Christian Democrats/Liberal Conservatives). Administrative leadership was provided by external powerful mayors. They served long terms and could easily dominate local politics. In terms of accountability, the city council only to a limited degree exercised political control on the way the city was governed ${ }^{9}$. Executive councillors

5 Retrieved from: http://www.apeldoorn.nl/ter/politiekenorganisatie/Plannen-en-projecten/ Plannen-en-projecten-Structuurvisie-Apeldoorn-biedt-ruimte.html

6 For more on Apeldoorns City District Approach: http://www.apeldoorn.nl/DATA/TER/docs/ politiek/dorps_wijkraden/stadsdeelaanpak\%20kadernotitie.pdf;

And for area oriented policy development: http://www.svgw.nl/wp-content/ uploads/2011/10/Voordracht-politieke-markt-Apeldoorn-23-juni.pdf

7 See http://www.binnenlandsbestuur.nl/bestuur-en-organisatie/achtergrond/achtergrond/ grote-stad-dik-in-de-ambtenaren.100094.lynkx

8 On the basis of Joint Intermunicipal regulations, with distanced (tiered) political control.

9 Raadsenquête (Council Inquest), rapport Dualisme \& Controle in Apeldoorn 2.0 (report Dualism \& Control in Apeldoorn 2.0). 
and the mayor dealt directly with local (social) entrepreneurs on the basis of a very wide and not explicit mandate.

The frontline between city government and citizens is formally structured as shown in Table 2.

Table 2: Structure of the frontline between city government and citizens

\begin{tabular}{|c|c|}
\hline \multirow{3}{*}{ 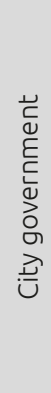 } & $\begin{array}{l}\text { council members: legislation, policymaking, budgeting, accountability } \\
\text { processes }\end{array}$ \\
\hline & $\begin{array}{l}\text { municipal executive board members: administration, policy initiation, political } \\
\text { contacting (city district executive councillor for daily administration affairs) }\end{array}$ \\
\hline & $\begin{array}{l}\text { civil servants: project managers (policy-development; project administration; } \\
\text { urban development projects) } \\
\text { - case-managers (administration in the domain of welfare; administration of } \\
\text { national regulation) } \\
\text { - operators (e.g. road maintenance, management public facilities; welfare } \\
\text { workers) } \\
\text { - neighbourhood managers (stimulating and facilitating social initiatives; } \\
\text { communicating municipal policies; developing neighbourhood plans) }\end{array}$ \\
\hline \multirow{3}{*}{$\frac{\text { त्ये }}{\stackrel{\frac{U}{U}}{\circ}}$} & $\begin{array}{l}\text { rganizations (CSOs): policy administration (in commission, often } \\
\text { ns) }\end{array}$ \\
\hline & $\begin{array}{l}\text { initiators of private (citizens, companies), social (associations) and } \\
\text { public (foundations) initiatives (both natural and economic legal entities } \\
\text { (companies) }\end{array}$ \\
\hline & $\begin{array}{l}\text { general public: elections for office, consultation, formal complaints and legal } \\
\text { actions }\end{array}$ \\
\hline
\end{tabular}

On this frontier, we mapped each of the three cases. Before presenting the analysis, we first briefly introduce each of the cases.

\section{Cases}

\subsection{De Maten}

In 'De Maten' city district, at the early and cold start of the winter of 2011/2012, local inhabitants were suddenly confronted with a winter shelter in an old scouting centre in the neighbourhood park. It had long been abandoned and was deemed unfit for lodging people 24/7. Nonetheless, the shelter had opened. A local church had taken initiative to provide winter shelter for homeless families roaming the streets of Apeldoorn. Most of these families refused to turn to the official shelters driven by a CSO welfare organisation that was fully financed by the city, wishing to stay in a drugs free and safe environment which the "official shelters" were perceived not to offer. The church community (three churches and a foundation) had requested the executive councillor in October to indicate a location, but he was weary, being advised by his experts that the official welfare organisation already provided a covering safety net for the homeless. He conceded however that, if they were to find a proper location, he would try his best to accommodate them. 
Subsequently, each location they came up with was turned down by local civil servants invoking official regulations, hazards or risks.

Two months later, winter set in. The church contacted local councillors and told them of their frustration not be able to start the shelter because the city administration refused to proactively cooperate. These councillors in turn contacted the executive councillor and within two days a location had been found. In a haste, without the proper permits, without informing the police, the official welfare organisation organizing shelter care and neighbouring inhabitants through the regular neighbourhood platform, the shelter was opened. In the neighbourhood, emotions ran high and stories of possible and actual risks circulated quickly.

After the initial start, passions quickly ceded. The shelter served only 26 homeless people. With 44 volunteers involved and 23.000 euros being spent, the church community tried to keep the shelter up and running by reportedly sending out cars to pick up people at other parts of the city and transport them to 'De Maten'. Afterwards, the official CSO complained of the high cost (marginal as well as per capita) of this voluntary shelter, offering to do it themselves next year, in a professional way with less cost.

\subsection{Loenen: Urban Development}

In the Apeldoorn village of 'Loenen', a private building company from within the village sought to redevelop a part of the village including commercial real estate into a residential area. A local developer had bought some of the houses to build a small new neighbourhood. The Apeldoorn Development Plan only allowed for some 40 houses to be built in Loenen in the upcoming ten years. Stretching the economic viability, the plan contained 40 houses and apartments.

Preparations started as early as 2004. For the plan, the real estate developer sought the cooperation with one of Apeldoorn's social housing corporations. In an effort to scale down the project to more village-like residential project, the municipality formulated a set of demands in terms of spatial quality that should be met for the city to be able to go along. As these demands could not be met within the original plan, the local developer started to try and acquire adjacent plots and premises. The local village committee was weary of the 'urban' feel that the realisation of this project would give to Loenen, but at the same time perceived the project as the only viable option for the village to build at all in the upcoming ten years. As time wore on, the project halted to a full standstill. New figures on the soundscape effect of the project led to new municipal requirements in terms of sound-isolation. Immediate neighbours tried to fight against the development, and with success. The housing cooperation, seeing how slowly the project developed, reduced its participation. This in effect meant that the big launching customer decreased its share, thereby negatively affecting the businesscase. 
Meanwhile, so much time and money had been invested in the project, both by the investor (money) and city government (time), and other projects stalled in order for this project to pass, that opposition from both the inhabitants and the public servants dissipated. From 2006-2007 on, all of the public servants advising on aspects of the plan one after the other, after voicing opposition, approved the plan. In May 2011, five years after the start, the plan reached the city council, to be rubberstamped. In comparison to what the project developer and the city representatives had set out to achieve, however, but without staunch support from the executive or clear expert advice supporting the project. The council looked at the proposal with fresh eyes, found a lack of clear professional (local public servants) and political (executive councillor) support and voted the plan off the table because no-one really seemed to "want" the plan.

At the point, the village representatives exploded: this had been the only chance at getting new houses for Loenen! Cancelling the project would probably mean the end of the building company and results in years of slums in Loenen. In an effort to repair the damage, a number of city councillors went to visit the village community and explain why they had voted as they had. Seeing what had happened, they realized that something had to be done. The plan was revived, slightly changed, brought back to the table and was adopted. But the tide had turned. In the midst of an economic crisis, it proved to be hard to develop a new residential area. In spite of a subvention from the regional government to start and build this project as pipeline anticyclic investment, the project still remains to be started. The village committee has a hotline now with the councillors involved, but the project is still in sketches.

\subsection{Zuidbroek: Infrastructure}

'Zuidbroek' is the last new city district of Apeldoorn under construction since 2003. To achieve a favourable mix of populations between Zuidbroek and existing adjacent districts, the city government of Apeldoorn sought to achieve maximum unity by linking its infrastructure to the existing road network leading out of the city. In the Masterplan Zuidbroek in 2003, the decision was taken to close an existing road (the Operettestreet) so that the older neighbourhoods would not be burdened excessively with outgoing traffic. Despite experts advising to go through various scenarios, the city choose the option that was the most beneficial to outgoing cyclists and that created only one exit out of the new neighbourhood. Estimates of the number of cars being in use in the future Zuidbroek were optimized.

As Zuidbroek started to be populated, more and more new inhabitants using their cars were feeling the downside of this decision. Popular protest arose among the new neighbours, the decision was contested and the city government decided to organize a creative meeting to consult the inhabitants on how the infrastructure should be redesigned. In the meeting, members of the city council actively participated, crafting their own solutions on the basis 
of what they heard. The alternative that came out of the meeting catered to all interests existing at that time, but was evidently not futureproof. If Zuidbroek continued to grow, the solution would actually become an obstacle. Nonetheless, under popular pressure, the executive council adopted this measure and implemented it, despite city government experts' criticism.

In a formal session of the city council, the council (being heavily lobbied by the newer inhabitants of Zuidbroek) reversed the executive councils decision. It adopted a resolution to open all of the previously existing roads for automobiles. In spite of heavy criticism from city government experts as well as public neighbourhood managers, the executive council chose to respect the council's decision and implement it. As a matter of fact, the formal Masterplan was amended and toppled. Meanwhile, many of the formal objections had reached the state of court procedures. When finally these objections reached the highest court, all of Apeldoorn's formal decisions were annulled, and Apeldoorn was charged by the courts to develop an entirely new decision.

\section{Mechanisms: Description}

\subsection{Rules of the Game}

City-citizens interactions in Apeldoorn appear to be strongly public oriented, formalized and structured towards municipal decision-making and cooperation between formal organizations. Apeldoorn uses five instruments to enhance citizen participation:

- the Future Agenda, developed once every four years by the citizens living a Neighbourhood in an interactive process conducted by the city Neighbourhood Manager, an urban civil servant hired and paid for by the city government;

- the biannual Neighbourhood Plan, officially defined as the outcome of the mediation between the demand of citizens (see Future Agenda) and the supply that the City of Apeldoorn and its official partners can publicly muster. This process is managed by the Neighbourhood executive councillor with support of the Neighbourhood Manager;

- an Action List, the compilation of actions flowing from the Neighbourhood Plan that serves as an instrument to enhance transparency of what the city government and its partners are doing; managed by Neighbourhood Manager;

- a financial incentive ordinance for civic initiatives "Premium on Action", to support the development of small initiatives (< 1000 Euros) by ordinary citizens;

- the Neighbourhood Platform where city government, its institutional partners (CSOs) and other institutions coordinate their actions in the neighbourhood. 
The City of Apeldoorn acknowledges a limited number of organizations as its partners: two (fully publicly funded) social partners that carry out many of the city's social programs; the social housing corporations; the police; and the formally acknowledged neighbourhood associations of citizens ${ }^{10}$. Other neighbourhood specific organisations, such as schools, churches, sports- and cultural organisations and associations of entrepreneurs can be invited to the Neighbourhood Platform.

The Neighbourhood Platform is managed by the Neighbourhood Manager. The style of the meetings is largely consultative; partners inform each other of their priorities and try to combine forces. New priorities are fed back to the Action list, the Neighbourhood Plan, the municipal safety plan and ultimately the Future Agenda. ${ }^{11}$ In addition to the neighbourhood platform, the city government organizes a network of neighbourhood safety prevention teams.

\subsection{Participation}

In all three cases initiative was sparked by individual citizens. The local government had its long-term planning and administration processes: designing a new urban infrastructure, allocating development plans among the various Apeldoorn villages for private developers to pick up and engage in dialogue with municipality, providing winter shelters through $100 \%$ subsidized professional social care foundation.

There was a clear tension between organized participation and direct participation. Individual initiatives ran counter to this distributive ratio: localized initiatives. More often than not, the initiatives were private: a church providing winter shelter for non-addict individuals and families that for personal reasons did not want to look for shelter in subsidized locations; an individual local builder developing a plan by acquiring real estate and redeveloping them; inhabitants protesting against the plans to connect a new development project by existing transit routes through their neighbourhood. Short term social micro politics conflicted with long term public macro politics. Neighbourhood committees were used by local politicians and public servants as sounding boards, but the lack of continuity (only 3-4 annual meetings) was insufficient to support the level of contact that was needed to build responsiveness and participation.

This led to a debate on the legitimacy of neighbourhood committees and the limited transparency of the way the municipality operates. The reliability and mandate of public neighbourhood frontliners was called into question. Informal and formal protests by inhabitants disturbed the local political process as well as policy implementation. Council members were shocked when they realized that the plans presented to them by the executive board had been

10 Retrieved from http://www.apeldoorn.n//DATA/TER/docs/politiek/dorps_wijkraden/ verordening_dorpsenwijkraden_2009_vs2.pdf

11 Retrieved from http://www.apeldoorn.n//DATA/TER/docs/politiek/dorps_wijkraden/ stadsdeelaanpak\%20kadernotitie.pdf 
part of a formal consultative process, but that there was no transparency for individual citizens (and subsequently criticism). Executive councillors brought plans to the municipal councils that they themselves were neutral too, or did not even support.

\subsection{Deliberation}

As to deliberation, the efforts to structurally connect local government with grass-roots initiatives seem fragment the deliberative process. More and more, substantive deliberation - the type we see in policy-initiatives being taken to the council - becomes disjointed from social politics. There, individual initiatives and complaints, stemming from micro politics, are directly channelled into the public deliberative process: either by civil servant neighbourhood frontliners, individual council members in their function as "people's tribunes" or executive council members in their consultation hours and neighbourhood visits.

Formal deliberative processes are essentially top down in nature: they focus on the implementation of city council decisions, formulating action plans, cooperating with formal partners such as welfare foundations and housing cooperations. In essence, both councillors and civil servants try to be as facilitative as possible and accommodate citizens, in line with the local consultative culture, but the vertical logic of implementation is often at odds with the horizontal logic of grass roots development.

Long term planning and policy processes are predominantly the domain of the city council. Neighbourhood committees formulate their five year priority future agendas, and the council tries to connect them to the formulation of bylaws, spatial plans and city budgets. There are much less suited as a locus where horizontal and vertical logics meet, yet this is precisely what happens.

Disjointedness leads to tension on a number of points. Individual citizens and entrepreneurs signal a lack of responsiveness. This lack stems not from the inability of city hall to cooperate and communicate with society. The style of urban governance can essentially be characterized as consultative. It has much more to do with the differences in rhythm and scope of micro and macro politics. The more city hall tries to be facilitative, the more apparent the differences in function of facilitating and governing becomes.

In all of the three cases, precisely because of its consultative style, local government failed to adequately organize the balance and coherence between micro and macro politics. The frameworks formulated by the city council were too abstract to function as a basis for citizen and private initiatives. Subsequently, collaborative urban governance led to initiatives that only at the end of the process of policy formulation showed the imbalance and inadequacy of local formal policies. As the council had to base itself on the frameworks to call the executive into account, it often lacked an adequate 
basis for evaluation and saw no other way than to follow the executive. Civil servants having to advise on either policies or concrete initiatives experienced little political guidance, little basis for independent expert advice and subsequently limited added value. Because of that, frontline public officials reported a gap between the logic of the situation that they operated in and the logic of the policies they had to carry out. Subsequently, CSOs, entrepreneurs' and citizen initiatives were furthered and promoted without a proper critical evaluation of how these fitted into city policies. Without any political backing, public servants that operated in direct contact with citizens developed risk aversion. Procedures were slowed down or even hatted, and policy advising was more often than not focused at building a dossier that would serve to stand up in court or under political scrutiny.

Because of this loss of sense and direction, citizens slowly lost clear view on what the city government wanted and how it operated. This could be called the paradox of collaborative decision-making: instead of increased trust and transparency, it can lead to estrangement of citizens from their government. The apparent loss of transparency and disjointedness of decision-making directly affects the legitimacy of the neighbourhood platforms. They become more and more formalized, attracting citizens that already know how to find their way through the maze of formal political decision-making. Losing their power as a platform for civic action as well as their function as a societal antenna, they too become part of the loss of transparency in the eyes of "individual" citizens.

\subsection{Empowerment}

To what extent is Apeldoorn's engagement policy empowering? Institutions such as neighbourhood committees are financed by municipality, run by interested citizens, with an independent board chosen in direct meetings. Their function is to provide an organized regular "venue" for contacts between neighbourhood participants and formal organizations such as municipality and social housing cooperations. They have independent statutes and boards, but are based on a frame laid down in a local bylaw to allow the city to support its functioning. Neighbourhood associations of citizens can only participate as "official representatives" if they are acknowledged as such on the basis of the local bylaw on Village- and Neighbourhood Committees. To do that, they must fulfil a number of statutory procedural obligations as to openness, free elections and minimal number of meetings. The association's board role ensures a cooperative sphere within the neighbourhood council and adequate staffing of the various voluntary neighbourhood committees.

In the three cases, the disjointedness of the process led to quite some stress for the neighbourhood committees. On the one hand, individual citizens were involved by concrete projects within their community, either as initiator, supporter or as opponent. They all dealt directly with the neighbourhood manager, who channelled their ideas, grievances and support 
into the formal process. On the other hand, there were citizens not being involved and weary: the sudden installation of a winter shelter in their back yard; the development of a housing project on a scale and location hitherto not expected; or newcomers protesting against the (proposed) infrastructure of their new neighbourhood, wanting to change the status quo. Only in 'De Maten', the neighbourhood committee effectively succeeded in rallying the neighbourhood inhabitants under one flag, serving as a communicative platform for the church that started the shelter, the municipality and individual citizens. In 'Loenen', the community lamented the location, scope and appearance of the project, but did not want to obstruct a fellow villager and mainly focused on getting something built, at all. In 'Zuidbroek', the neighbourhood committee was not able to effectively channel the broad spectre of support, anger and anxiety into a social debate.

\subsection{Control and Monitoring}

Structuring the boundary can help to enhance transparency. The structured way of working with a four and two year agenda under joint executive-citizen control and the action lists in itself provide a sound basis for civic control and monitoring of action. In the three cases, however, these lists failed. They were all focused on the steady implementation and administration of city funds and manpower (formal politics), and said nothing about the sudden and spontaneous initiatives and passions that characterize social politics - the focus on the short term. Somehow, it is hard to combine the two worlds of politics, yet this is exactly the frontier that neighbourhood managers operate upon.

The actual effect of Apeldoorn's city district approach on transparency depends on a number of factors. It relies on the quality and modus operandi of the neighbourhood managers, and their ability (as in a splits) to cater to the two very different rhythms and rules of the game. Because of the fragmentation of the two political processes (formal and social) and the haphazard feedback from individual initiatives into steady urban governance, the long term city development dashboards offered ever lesser guidance. Somehow, specifying the future in terms of substantial formal policy because of social politics led to policy "lock-in": a situation where a social problem is framed in such a way that future options are no longer attainable.

In each of these cases we found such "lock-ins". In 'De Maten', involving local communities in organizing and outsourcing winter shelters would have helped to have them more flexibly and timely involved. In 'Loenen', formulating a village housing policy rule that favoured redevelopment of commercial areas in combination with housing projects over pure housing projects created a deadlock on any development project, in turn necessitating direct involvement of city hall in an otherwise level playing field. In 'Zuidbroek', the future infrastructural grid was detailed to the nitty gritty to cater for the concerns of the current inhabitants of the neighbourhood. 


\section{Analysis}

In the cases that we studied, government and society follow different logics. So much is evident from this discussion of three cases of government participating in society and citizens participating in formal democratic processes. In this article, we have focused on the relation between organized transparency and formal politics. The selection processes focused on extreme cases from different domains, showing different logics, and representing different ways of organizing citizen engagement. The logics and mechanisms we found are in no way representative of the entire "world" of participative processes.

'Zuidbroek' is the most spontaneous case, and mostly about public urban governance. Citizens and civil-society-organisations hardly play a role in the development of the infrastructural grid. 'De Maten' shows how in social urban governance CSOs of various categories, neighbourhood managers and committees interact. It also highlights the grass roots orientation of city councillors "cutting through red tape" to realize concrete results that make it to the headlines. In addition, the case shows the trade off between voluntary and professional service delivery. In 'Loenen', a private entrepreneur sought to realize a project that would be a contribution to the city's policy. Here, the initiative was and remained private.

The participatory approach that Apeldoorn followed in these three cases can be described as collaborative, but the instruments used were geared towards involvement. This may be one of the explanations for the effects reported in this article.

\subsection{Skewing Representation}

As to the first hypothesis, the cases show little effects of participation on skewed representation. Although participation does appeal to the political gut feeling of councillors and provides them a platform for realizing concrete results, in formal politics the impact is limited. In the case of 'Zuidbroek', however, the newer (and more well to do, highly educated) inhabitants of Zuidbroek effectively captured one crucial council debate, toppling the Masterplan.

Formal, structured participation remains fundamentally open. One might question its relevance, the extent to which citizens objectives really have an impact on the way public expenditure is allotted and the size of the budget that they have a say on. There does seem to be a waning interest in formal participation, and informal actions such as those in Zuidbroek seem to be more effective in changing formal decision-making. 


\subsection{Fair and Impartial Procedure}

Impartiality is an issue in citizen engagement. Both the cases of Loenen and Zuidbroek shows how a strong collective of private interests can affect and change the transparency of formal procedures, and in 'De Maten' a small collective with the right contacts succeeded into securing a budget per client served that was much more favourable than the formally budgeted organization. As to fairness, there is certainly an issue of how criteria are interpreted and operationalized. In all of the three cases, formal criteria used by experts were easily reinterpreted or 'bent' so as to realize the public, social and private initiatives.

\subsection{Objectivity and Expertise}

Citizens nowadays can muster a level of expertise that the city's apparatuses lack. The disjointed and fragmented character of the participatory processes studied nicely shows how public procedure can profit from the information and realization potential that urban societies have. Whether neighbourhood committees are the appropriate means to that end, is debatable. Somehow, in spite of the neighbourhood committees being actively involved, large parts of the solutions that citizens could have delivered where not mobilized. Even to the contrary: sometimes the presence and inaptitude of neighbourhood committees can lead to "countering strategies": the organization of small groups that try to either tackle or capture the neighbourhood committees. The very public "formal politics" way in which they work is strongly at odds with the way in which inhabitants develop and coordinate their initiatives (social politics). The cost of all the procedures started in all three cases were enormous. For councillors this phenomenon is as attractive as a siren: impossible to ignore, dangerous to ride along with and very attractive to ride the waves. Populism and tendency to quickly "score" in the council.

Most of the cost here lies in the way public experts' advice was being handled. Consultative decision-making and loose, disjointed coupling in each of the cases led to the negation of experts' role in decision-making. The implication of this article is that the role of experts in participatory processes should be more closely investigated.

\subsection{The Social Contract: Burdening Tomorrow}

Participative decision-making, because of the disjointed character in these three cases, did lead to the externalisation of costs and risks: to homeless not serviced by the winter shelter in De Maten; to the inhabitants of Loenen who remained without new housing for a long period of years; and to the inhabitants of Zuidbroek (at first) and then Zevenhuizen.

Somehow, participation and solidarity are strongly at odds. This may be caused by the institutionalized way solidarity is organized (enforcing it by ordinances, 
bylaws and legislation), as compared to the individualist tendencies that participation evokes. The tension between continuous administration and facilitating individual private initiatives is hard to handle for city government.

\section{Conclusion and Implications}

Participatory democracy combines two processes that are highly different. Engagement has long been defined as supportive for and embedded in democracy. As an institutional phenomenon, formal participatory processes tend to be oriented towards representation: embedding groups, in a pyramidal way, into a system that creates mandates.

Blurring state-society relations and increased public-private-social participation tends to erode formal local decision-making. Put bluntly: open (urban) governance erodes local government. Embedding transparency, as we have seen, has the effect of suppressing individual voices. In modern day governance, citizens do not allow for suppression of social politics. They play the formal functions and systems to get what they want, and, at the same time, when the system needs them, they may not be interested. All in all, embedded participation in urban governance has the tendency to pervert formal democracy. Fair and impartial procedure; reliance on expert advice; representation; organized solidarity - individualized urban governance does not respect them.

Furthermore, this analysis suggests that the highest stages of public participation - collaboration and empowerment - can only be achieved by targeted transparency. That is: mandating disclosure of standardized, comparable, and disaggregated information regarding specific products or practices to a broad audience in order to achieve a specific public policy purpose. In the public domain, this is often related to concepts like "open information" and "open data". It not only pertains to the disclosure, but also to the form and format in which information is disclosed. To secure collaboration and empowerment, information should be disclosed in (open and transparent) forms, visualisations and formats that stimulate and empower citizens, local entrepreneurs and others to work with the data without having to go through the formal formation and socialization that public professionals go through traditionally. Although targeted transparency does not require specific technologies, it does often entail applying "civic and citizen tech" applications (Granier \& Kudo, 2015).

Most cities are still a long way off from targeted transparency, and so is the academic world (Meijer, Curtin, \& Hillebrandt, 2012; Meijer \& Bolívar, 2015) in its ability to closely study open governance. Efforts to enhance transparency and open governance should be studied as complex processes of institutional change and include normative and political aspects of applying specific means (nowadays: ICT) to open up government. Such analyses should focus on all five aspects of local governance: rules of the game, participation, the quality 
of deliberation, the distribution of power (empowerment) and control and monitoring effects. Studying open government efforts requires a much more critical normative approach than is often assumed - that is what these three case studies show us.

This assertion is not new. Most of the publications on the concept of open government have hinted at this. The contribution of this study lies in the shift towards the local level. This is where government and citizens interact, where (often) most public money gets spend, and where collaboration and empowerment may truly have effect. If the effort to increase the openness of government is to succeed at all, it should focus on the local level. As yet, in the Netherlands, open government has remained a central government theme (Jorna, 2015). Many of our participatory institutions on the local level are geared towards involvement. Collaborative and empowering democracy requires more collaborative platforms than neighbourhood committees.

Frans Jorna, PhD, is Chair of Governance at Saxion University of Applied Sciences. He publishes extensively on modern local governance, with specific interest for open government, smart cities, public-social-private partnership, civic participation, political-administrative relations and open data. He holds a doctoral degree in Public Administration from Leiden University (2009) and previously worked as a professor of Local Governance at the Lower Silesian College for the Public Service in Wroclaw, Silesia, Poland. Currently, he focuses on smart cities and the role that ICTs play in open government. 


\section{References}

Beck, U. (1992). Risk Society. Towards a New Modernity. Sage Publication Ltd.

Farrell, H., \& Drezner, D. W. (2008). The power and politics of blogs. Public Choice, 134(1), 15-30. DOI: $10.1007 / \mathrm{s} 11127-007-9198-1$

Goldstein, E., \& Dyson, L. (2013). Beyond Transparency: Open Data and the Future of Civic Innovation. Code for America Press.

Granier, B., \& Kudo, H. (2015). How are Citizens Involved in Smart Cities? Analyzing Citizen Participation in Japanese "Smart Communities". Paper presented at IRSPM 2015, unpublished.

Jorna, F. (2015). Open Government in the Netherlands. Progress Report. Open Government Partnership.

Keyne, J. (2009). The Life and Death of Democracy. W. W. Norton \& Company.

Krenjova, E., \& Reinsalu, K. (2014). Good Governance Starts from Procedural Changes: Casestudy of Preparing Participatory Budgeting in the City of Tartu. Socialiai Tyrimai, 3(32), 28-40.

Lindblom, C., \& Woodhouse, E. (1993). The Policy Making Process. Prentice Hall.

Marsh, D., Richards, D., \& Smith, M. (2003). Unequal Plurality: Towards an Asymmetric Power Model of British Politics. Government and Opposition, 38(3), 306-332.DOI: 10.1111/1477-7053.t01-1-00017

Meijer, A. J., Curtin, D., \& Hillebrandt, M. (2012). Open government: connecting vision and voice. International Review of Administrative Sciences, 78(1), 10-29. DOI: $10.1177 / 0020852311429533$

Meijer, A. J., \& Bolívar, M. P. R. (2015). Governing the city: a review of the literature on smart urban governance. International Review of Administrative Sciences, (published online before print, April 2015), 1-17. DOI: $10.1177 / 0020852314564308$

Newman, J., Barnes, M., Sullivan, H., \& Knops, A. (2004). Public participation and collaborative governance. Journal of Social Policy, 33(2), 203-223. DOI: $10.1017 /$ S0047279403007499

Sellers, J. (2010). State-Society Relations beyond the Weberian State. In: M. Bevir (Ed.), Handbook of Governance (pp. 124-141). Sage Publication.

Stoker, G. (2010). Building a new politics? New paradigms for public policy series. British Academy Policy Centre.

Townsend, A. (2013). Smart Cities: Big Data, Civic Hackers and the Quest for a New Utopia. W. W. Norton \& Company.

Weber, M. (2014). Wirtschaft und Gesellschaft. Saga Verlag.

Van Gunsteren, H. (2006). Vertrouwen in de democratie. Van Gennep.

Weintraub, J., \& Kumar, K. (Eds.). (1997). Public and Private in Thought and Practice: Perspectives on a Grand Dichotomy. University of Chicago Press. 
IZVLEČEK

1.02 Pregledni znanstveni članek

\section{Odprtost in urbano upravljanje: Kako preglednost spodkopava lokalno oblast}

Dandanes imajo lokalni politični voditelji težko delo. Vse bolj se namreč soočajo z občani, ki zahtevajo transparentnost in želijo imeti besedo pri ustvarjanju socialnih dobrin. Hegemonijo lokalne oblasti postavljajo pred izzive s povezovanjem svojih virov, s čimer želijo ustvariti sveže rešitve. Strah pred pravnimi spori, povečanje kompleksnosti oblikovanja politike in upravljanja ter pomanjkanje finančnih virov postavljajo lokalne uprave v položaj, ko si ne upajo tvegati.

Kako učinkovito strukturirati soočanje med lokalno oblastjo in lokalnimi skupnostmi? Pristopi odprtega in sodelovalnega upravljanja obetajo razvoj posredništva pri teh napetostih, toda kakšne so posledice za način delovanja lokalne demokracije, lokalne oblasti in lokalne uprave? Ta članek se na podlagi primerjalne študije primera iz Apeldoorna (Nizozemska) ozre na slabo stran zaupanja pri sodelovalnem in odprtem upravljanju. Članek identificira in analizira vzorce (pomanjkanja) odprtega upravljanja ter predlaga alternativne modele za organizacijo soočanja med lokalno oblastjo in družbo. 